\title{
Jointing patterns and tectonic evolution of the Maciço Calcário Estremenho, Lusitanian Basin, Portugal
}

Jorge M.F. Carvalho

LNEG - Laboratório Nacional de Energia e Geologia, IP, Apartado 7586 - Alfragide, 2610-999, Amadora, Portugal

\section{A R T I C L E I N F O}

\section{Keywords:}

Jointing patterns

Lusitanian basin

Tectonic evolution

\begin{abstract}
A B S T R A C T
The Maciço Calcário Estremenho (MCE) is an uplifted Jurassic limestone massif unit of the Lusitanian Basin, Portugal, where five main joint sets trending NNE-SSW, WSW-ENE, WNW-ESE, NW-SE, and NNW-SSE are recognized. Except for the NNW-SSE set, all the other sets host calcite veins and barren joints, evidencing a multistage development by several deformation episodes, including shear reactivation. Orthogonal patterns defined by the NNE-SSW/WNW-ESE and NNW-SSE/WSW-ENE systems are characteristic of some tectonostratigraphic units of the MCE, but the sets of each one of the systems are genetically independent. They result from specific deformation episodes undergone by the studied area in the course of its Meso-Cenozoic evolution. NNE-SSW calcite veins were the first to form during Middle Jurassic fault-controlled subsidence. A renewal of this set as barren joints took place during the Eocene Pyrenean compressive phase. The WSW-ENE and WNW-ESE sets have a restricted spatial distribution and relate to transient compressive episodes of the Middle - Late Jurassic and Jurassic - Cretaceous transitions, respectively. The NW-SE set, also characteristic of a specific region, formed during the Late Jurassic rifting and is related to local NE-SW tension dependent on block tilting towards a major NW-SE fault. The Miocene Betic compressive phase is responsible for the formation of the NNWSSE set, which is widespread throughout the MCE.
\end{abstract}

\section{Introduction}

A very well developed fracturing network marks the karst landscape of the Maciço Calcário Estremenho (MCE), which is the Portuguese name attributed by Martins (1949) to an uplifted Jurassic limestone massif in central Portugal. This network is very relevant regarding ornamental limestones extraction activities in the region and it is the support of one of the most important Portuguese fresh water aquifers. Nonetheless, apart from some local studies, no regional work has been carried out aiming to fully understand the dense network of fractures that characterizes the MCE.

A first look at the fracturing pattern of the outcrops in MCE reveals eye-catching arrangements of evenly spaced, parallel fractures that appear to correspond to joint sets. As mentioned by many authors, joints are among the most abundant geological structures. Occurring on different types of rocks and tectonic environments, these structures profoundly affect the physiography of the crust of the Earth, occurring in a wide diversity of rock types and tectonic environments (Pollard and Aydin, 1988; Davis et al., 2012).

Joints are the result of brittle deformation. They correspond to Mode I fractures that propagate normal to the least principal stress $\sigma 3$, in the plane containing $\sigma 1$ and $\sigma 2$, as a result of true tension $(\sigma 3<0)$ or, at deep levels in the Earth's crust, when tensile effective stress conditions are reached due to the presence of high fluid pressure (Engelder, 1987; Pollard and Segall, 1987; Price and Cosgrove, 1990). Because joints are parallel to the $\sigma 1-\sigma 2$ plane they are good paleostress indicators (Engelder and Geiser, 1980; Pollard and Aydin, 1988; Hancock and Engelder, 1989; Eyal, 2001), and for that they have been extensively used in regional field works (Engelder and Geiser, 1980; Hancock et al., 1991; Arlegui and Simón, 2001).

Commonly, joints occur in sets defining joint patterns. They are called systematic sets if the joints are planar, parallel, traceable for some distance, and regularly evenly spaced (Twiss and Moores, 1992; Davis et al., 2012). In layered sedimentary rocks the spacing is determined by the thickness of the mechanical layer (Narr and Suppe, 1991; Gross, 1993; Becker and Gross, 1996). Because joints may develop under very small differential stress (Engelder, 1993; Olson et al., 2009; Fossen, 2010), the orientation and spatial distribution of systematic sets of joints is very useful for determining regional variations on the stress field, taking into account the abutting relationships between joint sets (Engelder and Geiser, 1980; Dyer, 1988; Davis et al., 2012). However, the most common reasons to study joints are for hydrologic or engineering applications. In fact, joints play an important role on determining the preferential paths for fluid flow, on the

E-mail address: jorge.carvalho@lneg.pt. 